\title{
Methanotrophy within the water column of a large meromictic tropical lake (Lake Kivu, East Africa)
}

\author{
C. Morana ${ }^{1}$, A. V. Borges ${ }^{2}$, F. A. E. Roland ${ }^{2}$, F. Darchambeau ${ }^{2}$, J.-P. Descy ${ }^{3}$, and S. Bouillon ${ }^{1}$ \\ ${ }^{1}$ Department of Earth and Environmental Sciences, KU Leuven, Leuven, Belgium \\ ${ }^{2}$ Chemical Oceanography Unit, Université de Liège, Liege, Belgium \\ ${ }^{3}$ Research Unit in Environmental and Evolutionary Biology, UNamur, Namur, Belgium \\ Correspondence to: C. Morana (cedric.morana@ees.kuleuven.be)
}

Received: 9 October 2014 - Published in Biogeosciences Discuss.: 7 November 2014

Revised: 23 March 2015 - Accepted: 24 March 2015 - Published: 7 April 2015

\begin{abstract}
The permanently stratified Lake Kivu is one of the largest freshwater reservoirs of dissolved methane $\left(\mathrm{CH}_{4}\right)$ on Earth. Yet $\mathrm{CH}_{4}$ emissions from its surface to the atmosphere have been estimated to be 2 orders of magnitude lower than the $\mathrm{CH}_{4}$ upward flux to the mixed layer, suggesting that microbial $\mathrm{CH}_{4}$ oxidation is an important process within the water column. A combination of natural abundance stable carbon isotope analysis $\left(\delta^{13} \mathrm{C}\right)$ of several carbon pools and ${ }^{13} \mathrm{CH}_{4}$-labelling experiments was carried out during the rainy and dry season to quantify (i) the contribution of $\mathrm{CH}_{4}$-derived carbon to the biomass, (ii) methanotrophic bacterial production (MBP), and (iii) methanotrophic bacterial growth efficiency (MBGE), defined as the ratio between MBP and gross $\mathrm{CH}_{4}$ oxidation. We also investigated the distribution and the $\delta^{13} \mathrm{C}$ of specific phospholipid fatty acids (PLFAs), used as biomarkers for aerobic methanotrophs. Maximal MBP rates were measured in the oxycline, suggesting that $\mathrm{CH}_{4}$ oxidation was mainly driven by oxic processes. Moreover, our data revealed that methanotrophic organisms in the water column oxidized most of the upward flux of $\mathrm{CH}_{4}$, and that a significant amount of $\mathrm{CH}_{4}$-derived carbon was incorporated into the microbial biomass in the oxycline. The MBGE was variable (2-50\%) and negatively related to $\mathrm{CH}_{4}: \mathrm{O}_{2}$ molar ratios. Thus, a comparatively smaller fraction of $\mathrm{CH}_{4}$-derived carbon was incorporated into the cellular biomass in deeper waters, at the bottom of the oxycline where oxygen was scarce. The aerobic methanotrophic community was clearly dominated by type I methanotrophs and no evidence was found for an active involvement of type II methanotrophs in $\mathrm{CH}_{4}$ oxidation in Lake Kivu, based on fatty acids analyses. Vertically integrated over the water column,
\end{abstract}

the MBP was equivalent to $16-60 \%$ of the average phytoplankton particulate primary production. This relatively high magnitude of MBP, and the substantial contribution of $\mathrm{CH}_{4-}$ derived carbon to the overall biomass in the oxycline, suggest that methanotrophic bacteria could potentially sustain a significant fraction of the pelagic food web in the deep, meromictic Lake Kivu.

\section{Introduction}

Although the atmospheric methane $\left(\mathrm{CH}_{4}\right)$ concentration is low compared to carbon dioxide $\left(\mathrm{CO}_{2}\right), \mathrm{CH}_{4}$ contributes significantly to the anthropogenic radiative forcing (18\%) because of its 25 times higher global warming potential than $\mathrm{CO}_{2}$ (Forster et al., 2007). $\mathrm{CH}_{4}$ has several natural and anthropogenic sources and sinks, whereby natural and artificial wetlands are recognized as major $\mathrm{CH}_{4}$ sources to the atmosphere (e.g. Kirschke et al., 2013). Bastviken et al. (2011) estimated that $\mathrm{CH}_{4}$ emissions into the atmosphere from freshwater ecosystems $\left(0.65 \mathrm{Pg} \mathrm{C} \mathrm{yr}^{-1}\right.$ as $\mathrm{CO}_{2}$ equivalent) would correspond to $25 \%$ of the global land carbon (C) sink (2.6 $\pm 1.7 \mathrm{Pg} \mathrm{C} \mathrm{yr}^{-1}$, Denman et al., 2007). Tropical regions are responsible for approximately half of the estimated $\mathrm{CH}_{4}$ emissions from freshwater ecosystems to the atmosphere, although they have been consistently undersampled (Bastviken et al., 2011). Thus, more information on both the magnitude and controlling factors of $\mathrm{CH}_{4}$ emissions from tropical inland waters are warranted. $\mathrm{CH}_{4}$ production rates are typically higher than $\mathrm{CH}_{4}$ emission fluxes to the atmosphere, since aerobic and anaerobic microbial $\mathrm{CH}_{4}$ oxidation 
within lacustrine sediments or in water columns are effective processes that limit the amount of $\mathrm{CH}_{4}$ reaching the atmosphere, in particular when vertical $\mathrm{CH}_{4}$ transport occurs mainly through diffusive transport rather than through ebullition. A wide variety of electron acceptors can be used during microbial $\mathrm{CH}_{4}$ oxidation, including but not limited to oxygen $\left(\mathrm{O}_{2}\right.$, Rudd et al., 1974). The use of an enzyme known as $\mathrm{CH}_{4}$ monooxygenase to catalyze the oxidation of $\mathrm{CH}_{4}$ to methanol is a defining characteristic of aerobic methanotrophs (Hanson and Hanson, 1996). Methanol is then oxidized to formaldehyde, which is assimilated to form intermediates of central metabolic routes that are subsequently used for biosynthesis of cell material (Hanson and Hanson, 1996 and references therein). Hence, aerobic methanotrophs use $\mathrm{CH}_{4}$ not only as an energy source, but also as a $\mathrm{C}$ source. Aerobic methanotrophs are typically classified into two phylogenetically distinct groups that use different pathways for the formaldehyde assimilation: the type I methanotrophs belong to the Gammaproteobacteria and use the ribulose monophosphate pathway, while the type II methanotrophs belong to the Alphaproteobacteria and use the serine pathway.

Besides aerobic processes, anaerobic $\mathrm{CH}_{4}$ oxidation coupled with $\mathrm{SO}_{4}^{2-}$ reduction has been found to be carried out by a syntrophic consortium of $\mathrm{CH}_{4}$-oxidizing archaea and sulphate-reducing bacteria. The association between the archaea and bacteria is commonly interpreted as an obligate syntrophic interaction in which the archaeal member metabolizes $\mathrm{CH}_{4}$ leading to the production of an intermediate, which in turn is scavenged as an electron donor by its $\mathrm{SO}_{4}^{2-}$ reducing partner (Knitell and Boetius, 2009), but the identity of the intermediates transferred between the $\mathrm{CH}_{4}$ oxidizers and the $\mathrm{SO}_{4}^{2-}$ reducers is still uncertain. In contrast to aerobic $\mathrm{CH}_{4}$ oxidation, the contribution of $\mathrm{CH}_{4}$ as a $\mathrm{C}$ source would be minimal as only $\sim 1 \%$ of the oxidized $\mathrm{CH}_{4}$ is channelled to biosynthesis pathway, and the growth of the partners of the consortium is slow, with generation times of months to years (Knitell and Boetius, 2009). Both partners of the consortium are strictly intolerant to $\mathrm{O}_{2}$ (Knitell and Boetius, 2009). Initially reported in marine sediments (Boetius et al., 2000), this consortium was later identified in the water column of marine euxinic basins, such as the Black Sea (Schubert et al., 2006), but rarely in lacustrine systems probably because fresh waters are usually depleted in $\mathrm{SO}_{4}^{2-}$ in comparison with other electron acceptors $\left(\mathrm{NO}_{3}^{-}, \mathrm{Fe}^{3+}, \mathrm{Mn}^{4+}\right)$ in contrast with the oceans. Nevertheless, it appeared during the last decade that anaerobic $\mathrm{CH}_{4}$ oxidation could be coupled to a wider variety of electron acceptors that previously thought, including nitrite $\left(\mathrm{NO}_{2}^{-}\right)$, nitrate $\left(\mathrm{NO}_{3}^{-}\right)$, manganese $(\mathrm{Mn})$, and iron $(\mathrm{Fe})$ (Raghoebarsing et al., 2006; Beal et al., 2009).

Aerobic methanotrophic organisms not only use $\mathrm{CH}_{4}$ as electron donors, but they are also able to incorporate a substantial fraction of the $\mathrm{CH}_{4}$-derived $\mathrm{C}$ into their biomass, and could therefore contribute to fuel the pelagic food web (Bastviken et al., 2003; Jones and Grey, 2011; Sanseverino et al., 2012). A recent study carried out in small boreal lakes (surface area $<0.01 \mathrm{~km}^{2}$ ) demonstrated that methanotrophic bacterial production (MBP, i.e. incorporation rates of $\mathrm{CH}_{4}$ derived carbon into the biomass) contributed to $13-52 \%$ of the autochtonous primary production in the water column (Kankaala et al., 2013). However, in spite of the potential importance of this alternative $\mathrm{C}$ source in aquatic ecosystems, most of the studies carried out in aquatic environments reported gross $\mathrm{CH}_{4}$ oxidation, while direct measurements of MBP in lakes are still scarce. Also, the methanotrophic bacterial growth efficiency (MBGE), defined as the amount of biomass synthesized from $\mathrm{CH}_{4}$ per unit of $\mathrm{CH}_{4}$ oxidized, was found to vary widely in aquatic environments (15-80\% according to King, 1992; 6-77\% according to Bastviken et al., 2003), but little is known about the factors driving its variability so that it is currently not possible to derive accurate estimations of the MBP based solely on gross $\mathrm{CH}_{4}$ oxidation rates. A better understanding of the environmental control of MBGE would help to assess more accurately the importance of methanotrophic organisms as carbon sources for higher trophic level of the food web.

Lake Kivu, located in a volcanic area, is one of the largest freshwater $\mathrm{CH}_{4}$ reservoirs, with approximately $60 \mathrm{~km}^{2}$ (at standard temperature and pressure) dissolved in its permanently stratified water (Schmid et al., 2005). Although the deep layers of the lake contain a huge amount of dissolved $\mathrm{CH}_{4}$, Lake Kivu ranks globally among the lakes with the lowest $\mathrm{CH}_{4}$ emissions into the atmosphere (Borges et al., 2011). Moreover, the emission of $\mathrm{CH}_{4}$ from surface waters to the atmosphere $\left(0.038 \mathrm{mmol} \mathrm{m}^{-2} \mathrm{~d}^{-1}\right.$, Borges et al., 2011) is several orders of magnitude lower than the upward flux of $\mathrm{CH}_{4}$ to the mixed layer (9.38 $\mathrm{mmol} \mathrm{m}^{-2} \mathrm{~d}^{-1}$, Pasche et al., 2009), suggesting that $\mathrm{CH}_{4}$ oxidation prevents most of $\mathrm{CH}_{4}$ to reach the surface of the lake. Our knowledge on bacterial $\mathrm{CH}_{4}$ oxidation in Lake Kivu has so far been based on circumstantial evidence such as mass balance considerations (Borges et al., 2011; Pasche et al., 2011), identification of aerobic $\mathrm{CH}_{4}$ oxidizers using molecular tools (Pasche et al., 2011) and lipid analysis (Zigah et al., 2015), and a few incubations carried out almost 40 years ago (Jannasch, 1975).

In this study, we used the difference in $\mathrm{C}$ stable isotope abundance $\left(\delta^{13} \mathrm{C}\right)$ of different $\mathrm{C}$ sources to estimate the fraction of $\mathrm{CH}_{4}$ inputs to the mixed layer from deep waters that is microbially oxidized within the water column, and to quantify the relative contribution of $\mathrm{CH}_{4}$-derived $\mathrm{C}$ to the particulate biomass. Additionally, phospholipid fatty acids (PLFAs) and their $\delta^{13} \mathrm{C}$ signatures were analyzed to characterize the populations of methanotrophic bacteria present in the water column. We also carried out ${ }^{13} \mathrm{CH}_{4}$-labelling experiments to trace the incorporation of $\mathrm{CH}_{4}$-derived $\mathrm{C}$ into the biomass (to quantify methanotrophic bacterial production) and its conversion to $\mathrm{CO}_{2}$ (to quantify methanotrophic bacterial growth efficiency). Finally, stable isotope probing (SIP) of specific PLFAs (SIP-PLFAs) after ${ }^{13} \mathrm{C}_{-} \mathrm{CH}_{4}$ 


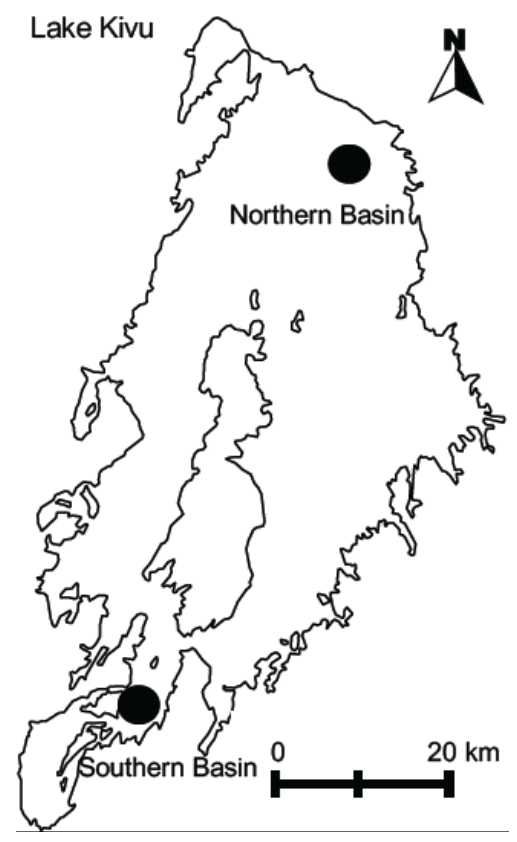

Figure 1. Map of Lake Kivu.

labelling allowed to characterize the bacterial populations active in methanotrophy.

\section{Material and methods}

\subsection{Study site description and sampling}

Lake Kivu (East Africa) is a large $\left(2370 \mathrm{~km}^{2}\right)$ and deep (maximum depth of $485 \mathrm{~m}$ ) meromictic lake. Its vertical structure consists of an oxic and nutrient-poor mixed layer (seasonally variable depth, up to $70 \mathrm{~m}$ ), and a permanently anoxic monimolimnion rich in dissolved gases $\left(\mathrm{CH}_{4}, \mathrm{CO}_{2}\right)$ and inorganic nutrients (Damas, 1937; Degens et al., 1973; Schmid et al., 2005). Seasonal variations of the vertical position of the oxycline are driven by contrasting hygrometry and long wave radiation between rainy (October-May) and dry (JuneSeptember) seasons (Thiery et al., 2014), the latter being characterized by a deepening of the oxic zone, and an increased input of dissolved gases and inorganic nutrients into the mixed layer (Sarmento et al., 2006, Borges et al., 2011). Sampling was carried out in the northern basin $\left(1.72^{\circ} \mathrm{S}\right.$, $29.23^{\circ} \mathrm{E}$ ) in February 2012 (rainy season), and in the northern basin and southern basin $\left(2.34^{\circ} \mathrm{S}, 28.98^{\circ} \mathrm{E}\right)$ in September 2012 (dry season, Fig. 1).

$\mathrm{O}_{2}$ concentration was measured with a YSI-proODO probe with a optical $\mathrm{O}_{2}$ sensor (detection limit is $3 \mu \mathrm{mol} \mathrm{L}{ }^{-1}$ ), calibrated using air saturated water. Hereafter, " $\mathrm{O}_{2}$-depleted waters" stands for waters with concentration $<3 \mu \mathrm{mol} \mathrm{L}{ }^{-1}$. Lake water was collected with a $7 \mathrm{~L}$ Niskin bottle (Hydro-Bios) at a depth interval of $5 \mathrm{~m}$ from the lake surface to the top of the monimolimnion, at $80 \mathrm{~m}$.

\subsection{Chemical analyses}

Samples for $\mathrm{CH}_{4}$ concentrations were collected in $50 \mathrm{~mL}$ glass serum bottles from the Niskin bottle with a silicone tubing, left to overflow, poisoned with $100 \mu \mathrm{L}$ of saturated $\mathrm{HgCl}_{2}$ and sealed with butyl stoppers and aluminium caps. Concentrations of $\mathrm{CH} 4$ were measured by headspace technique (Weiss, 1981) using gas chromatography with flame ionization detection (GC-FID, SRI 8610C), after creating a $20 \mathrm{~mL}$ headspace with $\mathrm{N}_{2}$ in the glass serum bottles. The GCFID was calibrated with $\mathrm{CH}_{4}: \mathrm{CO}_{2}: \mathrm{N}_{2} \mathrm{O}: \mathrm{N}_{2}$ mixtures (Air Liquide Belgium) of $1.05 \pm 0.02,10.2 \pm 0.2,30.3 \pm 0.6$ and $509 \pm 10 \mathrm{ppm} \mathrm{CH}_{4}$. Precision estimated from multiple injections of gas standards was better than $\pm 3 \%$ for the $1.05 \mathrm{ppm}$ standard and better than $\pm 0.5 \%$ for the other three standards. The precision estimated from duplicated samples was $\pm 3.9 \%$. The concentrations were computed using the $\mathrm{CH}_{4}$ solubility coefficient given by Yamamoto et al. (1976). Samples for the determination of the $\delta^{13} \mathrm{C}$ signature of $\mathrm{CH}_{4}$ $\left(\delta^{13} \mathrm{C}-\mathrm{CH}_{4}\right)$ were collected in $250 \mathrm{~mL}$ glass serum bottles similarly to $\mathrm{CH}_{4}$ concentration samples. $\delta^{13}{\mathrm{C}-\mathrm{CH}_{4}}_{4}$ was determined by a custom developed technique, whereby a $20 \mathrm{~mL}$ helium headspace was first created, and $\mathrm{CH}_{4}$ was flushed out through a double-hole needle, $\mathrm{CO}_{2}$ was removed with a $\mathrm{CO}_{2}$ trap (soda lime), and the $\mathrm{CH}_{4}$ was converted to $\mathrm{CO}_{2}$ in an online combustion column similar to that in an elemental analyzer (EA). The resulting $\mathrm{CO}_{2}$ was subsequently preconcentrated by the immersion of a stainless steel loop in liquid nitrogen in a custom-built cryo-focussing device, passed through a micro-packed GC column (HayeSep Q 2 m, $0.75 \mathrm{~mm}$ ID; Restek), and finally measured on a Thermo Scientific Delta V Advantage isotope ratio mass spectrometer (IRMS). Certified reference standards for $\delta^{13} \mathrm{C}$ analysis (IAEA-CO1 and LSVEC) were used to calibrate $\delta^{13} \mathrm{C}_{-} \mathrm{CH}_{4}$ data. Reproducibility of measurement estimated based on duplicate injection of a selection of samples was typically better than $\pm 0.5 \%$, or better than $\pm 0.2 \%$ o when estimated based on multiple injection of standard gas.

Samples for the determination of $\delta^{13} \mathrm{C}$ signatures of dissolved inorganic carbon (DIC) were collected by gently overfilling $12 \mathrm{~mL}$ glass vial (Labco Exetainer), preserved with $20 \mu \mathrm{L}$ of saturated $\mathrm{HgCl}_{2}$. For the analysis of $\delta^{13} \mathrm{C}$-DIC, a $2 \mathrm{~mL}$ helium headspace was created, and $100 \mu \mathrm{L}$ of $\mathrm{H}_{3} \mathrm{PO}_{4}$ $(99 \%)$ was added into each vial to convert all DIC species into $\mathrm{CO}_{2}$. After overnight equilibration, a variable volume of the headspace was injected into an EA coupled to an isotope ratio mass spectrometer (EA-IRMS; Thermo Scientific Flash HT with Thermo Scientific Delta V Advantage). Calibration of $\delta^{13} \mathrm{C}$-DIC measurements was performed with certified reference materials (LSVEC and either NBS-19 or IAEA-CO1) and the reproducibility of the measurement was always better than $\pm 0.2 \%$.

Samples for particulate organic carbon (POC) concentrations and its stable $\mathrm{C}$ isotope signature $\left(\delta^{13} \mathrm{C}\right.$-POC) were filtered on pre-combusted (overnight at $450^{\circ} \mathrm{C}$ ) $25 \mathrm{~mm}$ glass 
fiber filters (Advantec GF-75; $0.3 \mu \mathrm{m}$ ), and dried. These filters were later decarbonated with $\mathrm{HCl}$ fumes for $4 \mathrm{~h}$, dried, and packed in silver cups. POC and $\delta^{13} \mathrm{C}$-POC were determined on an EA-IRMS (Thermo Scientific Flash HT with Thermo Scientific Delta V Advantage). Calibration of POC and $\delta^{13} \mathrm{C}-\mathrm{POC}$ was performed with IAEA-C6 and acetanilide, and reproducibility of $\delta^{13} \mathrm{C}$-POC measurements, estimated based on triplicate measurements of standard, was typically better than $0.2 \%$.

Samples $(\sim 2 \mathrm{~L})$ for measurements of phospholipid fatty acid concentrations (PLFAs) and their $\delta^{13} \mathrm{C}$ signature were filtered on pre-combusted $47 \mathrm{~mm}$ glass fiber filters (Advantec GF-75; $0.3 \mu \mathrm{m}$ ), and kept frozen until further processing. Extraction and derivatization of PLFAs was performed following a modified Bligh and Dyer extraction, silica column partitioning, and mild alkaline transmethylation as described by Boschker et al. (2004). Analyses were made on a Isolink GC-c-IRMS coupled to a Thermo Scientific Delta $\mathrm{V}$ Advantage. All samples were analyzed in splitless mode, using an apolar GC column (Agilent DB-5) with a flow rate of $2 \mathrm{~mL} \mathrm{~min}^{-1}$ of helium as carrier gas. Initial oven temperature was set at $60^{\circ} \mathrm{C}$ for $1 \mathrm{~min}$, then increased to $130^{\circ} \mathrm{C}$ at $40^{\circ} \mathrm{C} \mathrm{min}^{-1}$, and subsequently reached $250^{\circ} \mathrm{C}$ at a rate of $3^{\circ} \mathrm{C} \mathrm{min}^{-1} \cdot \delta^{13} \mathrm{C}$-PLFAs were corrected for the addition of the methyl group by a simple mass balance calculation, and were calibrated using internal (C19:0) and external (mixture of C14:0, C16:0, C18:0, C20:0, C22:0) fatty acid methyl ester (FAME) standards. Reproducibility estimated based on replicates measurement was $\pm 0.6 \%$ or better for natural abundance samples.

\subsection{Determination of the isotope fractionation factor}

In September 2012 (southern basin), the isotope fractionation factor $(\varepsilon)$ was estimated by monitoring the changes in $\mathrm{CH}_{4}$ concentration and $\delta^{13} \mathrm{C}-\mathrm{CH}_{4}$ over time in microcosms at several depths $(60,62.5,65,67.5 \mathrm{~m})$ across the oxycline. Six glass serum bottles $(60 \mathrm{~mL})$ were gently overfilled at each depth and tightly capped with a butyl rubber stopper and an aluminium cap. They were then incubated in the dark at the lake temperature during $0,24,48,72,96$ or $120 \mathrm{~h}$. The incubation was stopped by poisoning the bottles with $100 \mu \mathrm{L}$ of saturated $\mathrm{HgCl}_{2}$. The measurement of the concentration of $\mathrm{CH}_{4}$ and the $\delta^{13} \mathrm{C}_{-} \mathrm{CH}_{4}$ in every bottle was performed as described before. The isotope fractionation factor was calculated according to Coleman et al. (1981).

\subsection{Methanotrophic bacterial production and growth efficiency measurement}

At several depths throughout the water column, the methanotrophic bacterial production and methanotrophic bacterial growth efficiency were estimated by quantifying the incorporation of ${ }^{13} \mathrm{C}$-labelled $\mathrm{CH}_{4}\left({ }^{13} \mathrm{C}-\mathrm{CH}_{4}, 99.9 \%\right.$, Eurisotop) into the POC and DIC pool. Water from each sampling depth was transferred with a silicone tubing into 12 serum bottles $(60 \mathrm{~mL})$, capped with butyl stoppers and sealed with aluminium caps. Thereafter, four different volumes $(50,100$, 150 , or $200 \mu \mathrm{L}$ ) of a ${ }^{13} \mathrm{C}_{-} \mathrm{CH}_{4}$ gas mixture $(1: 10 \mathrm{in} \mathrm{He})$ were injected in triplicate and $100 \mu \mathrm{L}$ of saturated $\mathrm{HgCl}_{2}$ was immediately added to one bottle per gas concentration treatment, serving as control bottle without biological activity. After vigorous shaking, the bottles were incubated in the dark during $24 \mathrm{~h}$ at the lake temperature. The incubation was stopped by filtration of a $40 \mathrm{~mL}$ subsample on $25 \mathrm{~mm}$ glass fiber filters (Advantec GF-75; $0.3 \mu \mathrm{m}$ ) to measure the ${ }^{13} \mathrm{C}$ POC enrichment, and a $12 \mathrm{~mL}$ Exetainer was filled and poisoned with the addition of $\mathrm{HgCl}_{2}$ in order to measure the ${ }^{13} \mathrm{C}$ DIC enrichment. The exact amount of ${ }^{13} \mathrm{C}_{-} \mathrm{CH}_{4}$ added in the bottles was determined from the bottles poisoned at the beginning of the experiment. The measurements of the concentration of POC, the $\delta^{13} \mathrm{C}$-POC, the $\delta^{13} \mathrm{C}$-DIC and the $\delta^{13} \mathrm{C}$ $\mathrm{CH}_{4}$ were performed as described above. Methanotrophic bacterial production (MBP, $\mu \mathrm{mol} \mathrm{L}^{-1} \mathrm{~d}^{-1}$ ) rates were calculated according to Hama et al. (1983):

$$
\begin{aligned}
& \mathrm{MBP}=\mathrm{POC}_{\mathrm{f}} \cdot\left(\%^{13} \mathrm{C}-\mathrm{POC}_{\mathrm{f}}-\%{ }^{13} \mathrm{C}-\mathrm{POC}_{\mathrm{i}}\right) / \\
& \left(t \cdot\left(\%{ }^{13} \mathrm{C}-\mathrm{CH}_{4}-\%{ }^{13} \mathrm{C}-\mathrm{POC}_{\mathrm{i}}\right)\right)
\end{aligned}
$$

where $\mathrm{POC}_{\mathrm{f}}$ is the concentration of $\mathrm{POC}$ at the end of incubation $\left(\mu \mathrm{mol} \mathrm{L}{ }^{-1}\right), \%{ }^{13} \mathrm{C}-\mathrm{POC}_{\mathrm{f}}$ and $\%{ }^{13} \mathrm{C}-\mathrm{POC}_{\mathrm{i}}$ are the percentage of ${ }^{13} \mathrm{C}$ in the $\mathrm{POC}$ and the end and the beginning of incubation, $t$ is the incubation time $\left(\mathrm{d}^{-1}\right)$ and $\%{ }^{13} \mathrm{C}-\mathrm{CH}_{4}$ is the percentage of ${ }^{13} \mathrm{C}$ in $\mathrm{CH}_{4}$ directly after the inoculation of the bottles with the ${ }^{13} \mathrm{C}$ tracer. The methanotrophic bacterial respiration rates (MBR, $\mu \mathrm{mol} \mathrm{L} \mathrm{L}^{-1} \mathrm{~d}^{-1}$ ) were calculated according to

$$
\begin{aligned}
& \mathrm{MBR}=\mathrm{DIC}_{\mathrm{f}} \cdot\left(\%^{13} \mathrm{C}-\mathrm{DIC}_{\mathrm{f}}-\%^{13} \mathrm{C}-\mathrm{DIC}_{\mathrm{i}}\right) \\
& \left(t \cdot\left(\%^{13} \mathrm{C}-\mathrm{CH}_{4}-\%{ }^{13} \mathrm{C}-\mathrm{DIC} \mathrm{i}\right)\right)
\end{aligned}
$$

where $\mathrm{DIC}_{\mathrm{f}}$ is the concentration of DIC after the incubation $\left(\mu \mathrm{mol} \mathrm{L}{ }^{-1}\right), \%{ }^{13} \mathrm{C}-\mathrm{DIC} \mathrm{C}_{\mathrm{f}}$ and $\%{ }^{13} \mathrm{C}-\mathrm{DIC} \mathrm{C}_{\mathrm{i}}$ are the final and initial percentage of ${ }^{13} \mathrm{C}$ in DIC. Finally, the methanotrophic bacterial growth efficiency (MBGE, \%) was calculated according to

$$
\mathrm{MBGE}=\mathrm{MBP} /(\mathrm{MBP}+\mathrm{MBR}) \cdot 100 .
$$

The $\mathrm{CH}_{4}$ concentration in the bottles sometimes increased drastically because of the ${ }^{13} \mathrm{C}_{-} \mathrm{CH}_{4}$ addition, which could have induced a bias in the estimation of MBP and MBR in case of $\mathrm{CH}_{4}$-limitation of the methanotrophic bacteria community. However, performing incubation along a gradient of $\mathrm{CH}_{4}$ concentrations allowed us to assess if the measured MBP and MBR were positively related to the amount of tracer inoculated in the bottles. In case of such an effect (only at $50 \mathrm{~m}$ in the northern basin in February 2012 and at $60 \mathrm{~m}$ in the southern basin in September 2012) we applied a linear 
regression model ( $r^{2}$ always better than 0.90$)$ to estimate the intercept with the $y$ axis, which was assumed to correspond to the MBP or MBR rates at in situ $\mathrm{CH}_{4}$ concentration.

\subsection{Stable isotope probing of PLFAs (SIP-PLFAs) with ${ }^{13} \mathrm{C}-\mathrm{CH}_{4}$}

At each sampling depth and in parallel with the MBP measurement, four serum bottles $(250 \mathrm{~mL})$ were filled with water, overflowed and sealed with butyl stopper and aluminium caps. Bottles were spiked with $500 \mu \mathrm{L}$ of ${ }^{13} \mathrm{C}_{-} \mathrm{CH}_{4}(99.9 \%)$. After $24 \mathrm{~h}$ of incubation in the dark at lake temperature, the water from the four bottles was combined and filtered on a single pre-combusted $47 \mathrm{~mm}$ glass fiber filter (Advantec GF$75 ; 0.3 \mu \mathrm{m})$ to quantify the incorporation of the tracer in bacterial PLFAs. The filters were kept frozen until further processing. The extraction, derivatization and analysis by GC-cIRMS were carried out as described above.

\section{Results}

\subsection{Physico-chemical parameters}

In September 2012, the water column in the southern basin was oxic $\left(>3 \mu \mathrm{mol} \mathrm{L}^{-1}\right)$ from the surface to $65 \mathrm{~m}$ (Fig. 2a). $\mathrm{CH}_{4}$ was abundant in deep waters, with a maximum concentration of $899 \mu \mathrm{mol} \mathrm{L}^{-1}$ at $80 \mathrm{~m}$; however, $\mathrm{CH}_{4}$ decreased abruptly at the bottom of the oxycline, being 4 orders of magnitude lower in surface waters (Fig. 2a). Consistent with its biogenic origin, $\mathrm{CH}_{4}$ was depleted in ${ }^{13} \mathrm{C}$ in deep waters $\left(\delta^{13} \mathrm{C}_{-} \mathrm{CH}_{4}:-55.0 \%\right.$ ) but became abruptly enriched in ${ }^{13} \mathrm{C}$ at the transition between oxic and $\mathrm{O}_{2}$-depleted waters, where $\mathrm{CH}_{4}$ concentrations sharply decreased, to reach a maximal value of $-39.0 \%$ at $62.5 \mathrm{~m}$ depth (Fig. 2a). The $\delta^{13} \mathrm{C}-\mathrm{POC}$ values mirrored the pattern of $\delta^{13} \mathrm{C}^{-\mathrm{CH}_{4}}$; they were almost constant from the surface to $55 \mathrm{~m}(-24.4 \pm 0.3 \%$ ), then showed an abrupt excursion towards more negative values at the bottom of the oxycline, with a minimum value $(-42.8 \%$ o) at $65 \mathrm{~m}$ depth (Fig. 2a). Similar results were found in September 2012 in the northern basin, where the water was oxic (> $3 \mu \mathrm{mol} \mathrm{L}{ }^{-1}$ ) down to $55 \mathrm{~m}$ (Fig. 2b). At the transition between oxic and $\mathrm{O}_{2}$-depleted waters, an abrupt isotopic enrichment of the $\mathrm{CH}_{4}$ was also observed and the $\delta^{13} \mathrm{C}-\mathrm{POC}$ was relatively depleted in ${ }^{13} \mathrm{C}$, similarly as in the southern basin (Fig. 2b).

In February 2012 in the northern basin, the water was oxic (> $3 \mu \mathrm{mol} \mathrm{L}^{-1}$ ) until $45 \mathrm{~m}$ depth, but the $\mathrm{O}_{2}$ concentrations were below the limit of detection deeper in the water column (Fig. 2c). The gradual decrease in the $\mathrm{CH}_{4}$ concentration between 60 and $45 \mathrm{~m}$ (from 110 to $3 \mu \mathrm{mol} \mathrm{L}^{-1}$ ) was accompanied by a parallel increase of the $\delta^{13} \mathrm{C}^{-} \mathrm{CH}_{4}$ signature in the same depth interval (from -55.9 to $-41.7 \%$ ), the residual $\mathrm{CH}_{4}$ becoming isotopically enriched as $\mathrm{CH}_{4}$ concentration decreased (Fig. 2c). $\delta^{13} \mathrm{C}-\mathrm{POC}$ values were also slightly lower below the oxic zone, with a minimum at $50 \mathrm{~m}$ $(-26.9 \%$; Fig. 2c).

\subsection{Phospholipid fatty acid concentration and stable isotopic composition}

Figure 3 show profiles of the relative concentration and the $\delta^{13} \mathrm{C}$ signature of specific PLFAs in September 2012 (Fig. 3a, b; southern basin) and February 2012 (Fig. 3c, d; northern basin). Irrespective of station, season and depth, the C16: 0 saturated PLFAs was always the most abundant PLFAs (18-35\% of all PLFAs). The relative abundance of the C16 monounsaturated fatty acids (C16 MUFAs) significantly increased at the bottom of the oxycline in February and September 2012. The $\delta^{13} \mathrm{C}$ signature of the $\mathrm{C} 16 \mathrm{MU}$ FAs was comparable to the $\delta^{13} \mathrm{C}$ signature of the $\mathrm{C} 16: 0$ in oxic waters, oscillating around -27 or $-29 \%$ in February and September 2012, respectively. However, C16 MUFAs were largely depleted in ${ }^{13} \mathrm{C}$ in the oxycline, with minimal ${ }^{13} \mathrm{C}$ values as low as $-55.3 \%$ at the transition between oxic and $\mathrm{O}_{2}$-depleted waters in September 2012, and $-49.5 \%$ in February 2012. This very strong depletion in $\delta^{13} \mathrm{C}$ was only observed for this particular type of PLFAs (C16 MUFAs). The C18 MUFA were slightly more abundant in oxic waters (on average $9 \%$ ) than in deeper waters (1-4\%). Their isotopic composition varied with depth following the same vertical pattern than C16 MUFAs, but with a lower amplitude. C18 MUFA minima in $\delta^{13} \mathrm{C}$ were observed in $\mathrm{O}_{2}$-depleted waters in February $2012(55 \mathrm{~m},-35.1 \%$ ) and September $2012(70 \mathrm{~m},-30.5 \%$ o $)$. The relative abundance of iso- and anteiso-branched C15 : 0 PLFAs was systematically low (1$5 \%$ ) and did not follow any depth pattern. Their isotopic signature was however slightly lower in $\mathrm{O}_{2}$-depleted waters than in oxic waters.

\subsection{Isotope fractionation factor determination}

During the isotope fractionation factor experiment, a significant decrease of the $\mathrm{CH}_{4}$ concentration over time and a parallel enrichment of the residual $\mathrm{CH}_{4}$ (Fig. 4) were monitored in every bottle incubated under oxic conditions. However, no consumption of $\mathrm{CH}_{4}$ was measured in $\mathrm{O}_{2}$-depleted waters. The isotope fractionation factor measured at several depths across the oxycline ranged between 1.008 and 1.024, and averaged $1.016 \pm 0.007(n=5)$.

\subsection{Methanotrophic bacterial production}

MBP rates within the oxycline were variable (from 0 to $\left.7.0 \mu \mathrm{molC} \mathrm{L}^{-1} \mathrm{~d}^{-1}\right)$. Maximum values were always observed at the bottom of the oxycline, near the transition between oxic and $\mathrm{O}_{2}$-depleted waters (Fig. 2d, e, f); however substantial MBP (up to $2.2 \mu \mathrm{mol} \mathrm{L}^{-1} \mathrm{~d}^{-1}$ ) were also recorded in $\mathrm{O}_{2}$-depleted waters in February 2012 (Fig. 2f). Vertically integrated over the water column, MBP rates were estimated at 28.6 and $8.2 \mathrm{mmol} \mathrm{m}^{-2} \mathrm{~d}^{-1}$ in September 

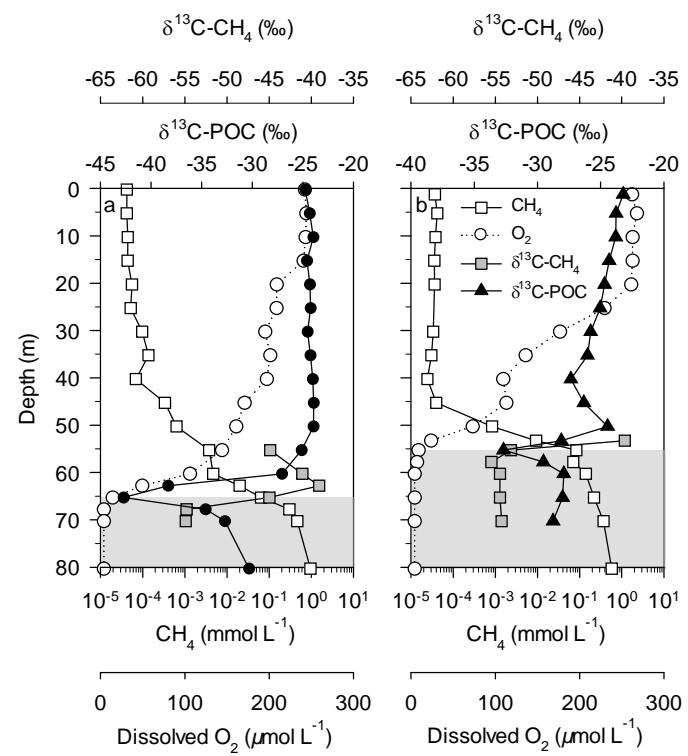

$\delta^{13} \mathrm{C}-\mathrm{CH}_{4}(\%)$
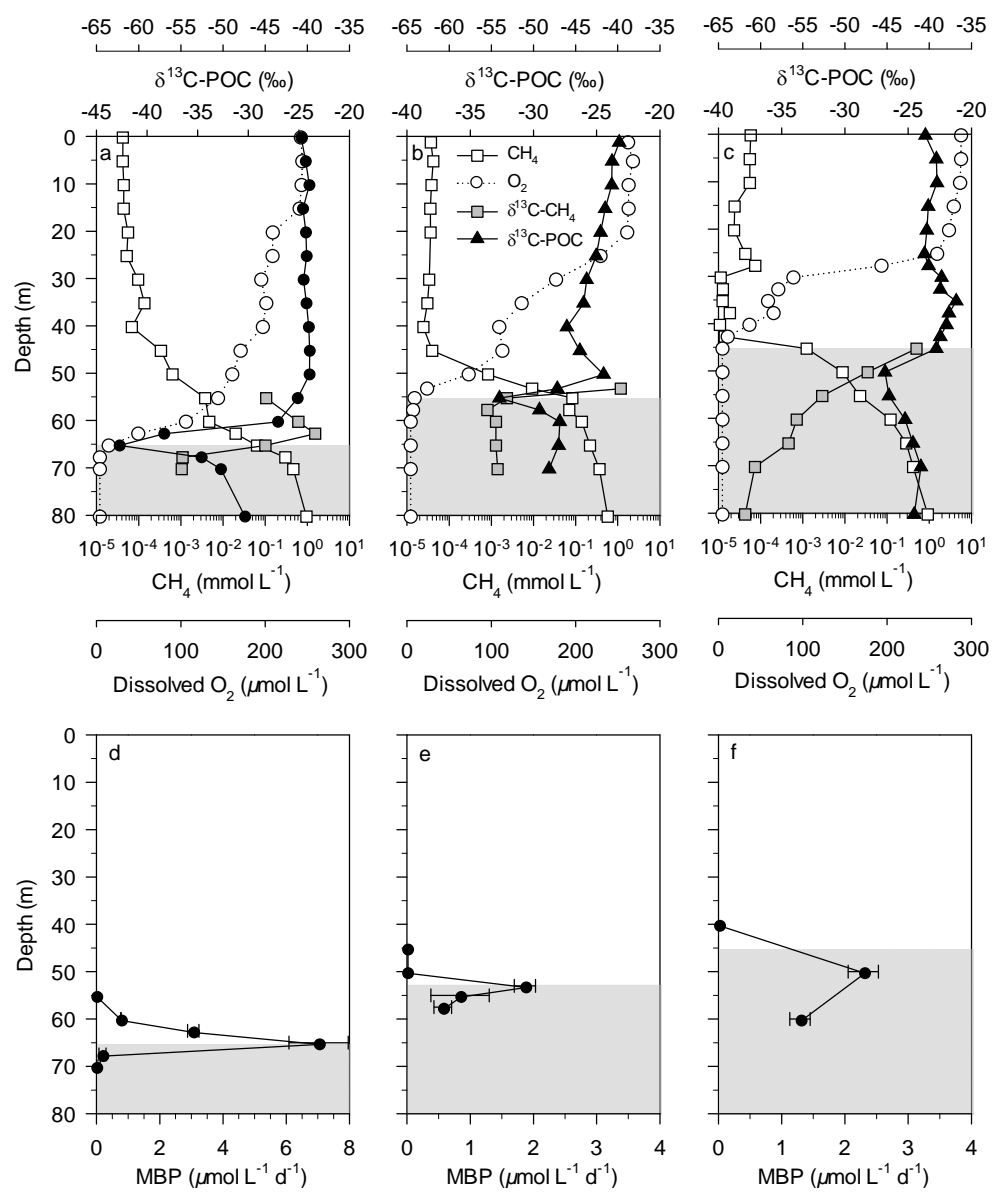

Figure 2. Vertical profiles of dissolved $\mathrm{O}_{2}$ concentration $\left(\mu \mathrm{mol} \mathrm{L}{ }^{-1}\right), \mathrm{CH}_{4}$ concentration $\left(\mathrm{mmol} \mathrm{L}^{-1}\right), \delta^{13} \mathrm{C}-\mathrm{CH} 4(\% o)$ and $\delta^{13} \mathrm{C}-\mathrm{POC}(\% o)$ in Lake Kivu, in September 2012 (dry season) in the southern basin (a) and northern basin (b), and in February 2012 (rainy season) in the northern basin (c). Information about the precision of measurement can be found in the material and methods section. Vertical profiles of methanotrophic bacterial production rates (MBP, $\left.\mu \mathrm{mol} \mathrm{L}^{-1} \mathrm{~d}^{-1}\right)$ in September 2012 in the southern basin (d) and northern basin (e) and in February 2012 in the northern basin (f). Symbols in (d), (e), and (f) represent mean values. Horizontal error bars represent standard deviation of replicates, when larger than the data point size. The grey zone corresponds to waters with dissolved $\mathrm{O}_{2}$ concentration $<3 \mu$ mol $\mathrm{L}^{-1}$.

2012 in the southern and northern basin, respectively, and $29.5 \mathrm{mmol} \mathrm{m}^{-2} \mathrm{~d}^{-1}$ in February 2012 in the northern basin. MBGE was found to be highly variable in the water column ranging between $50 \%$ at $52.5 \mathrm{~m}$ in the northern basin (September 2012) and $2 \%$ at $67.5 \mathrm{~m}$ in the southern basin (September 2012). Computed from depth-integrated MBP and MBR rates, the water column mean MBGE were $23 \%$ in September 2012 in the southern and northern basins, and $42 \%$ in February 2012 in the northern basin.

Specific $\mathrm{CH}_{4}$-derived $\mathrm{C}$ incorporation rates in PLFAs $\left(\mathrm{d}^{-1}\right.$; incorporation rates normalized on PLFA concentration) show that bacteria containing C16 MUFA and C14:0 were particularly active in $\mathrm{CH}_{4}$-derived $\mathrm{C}$ fixation in the oxycline in February and September 2012 (Figs. 5a, 4b). In contrast, the specific incorporation pattern was dominated by C17 MUFA, and to a lesser extent 10Me16:0 and C16 MUFA in $\mathrm{O}_{2}$-depleted waters in February 2012 (Fig. 5b).

\section{Discussion}

The sharp decrease of $\mathrm{CH}_{4}$ concentration and the isotopic enrichment of the residual $\mathrm{CH}_{4}$ in the oxycline, mirrored by the isotopic depletion of the POC pool at these depths indicated that microbial $\mathrm{CH}_{4}$ oxidation is a strong $\mathrm{CH}_{4}$ sink within the water column of Lake Kivu. Similar patterns characterized by a strong isotopic depletion of the POC pool in the oxycline were reported in other systems, such as the meromictic northern basin of Lake Lugano (Lehmann et al., 2004; Blees et al., 2014). The fraction of the upward $\mathrm{CH}_{4}$ flux oxidized within a depth interval can be estimated from a closed-system Rayleigh model of isotope fractionation (Blees et al., 2014) 

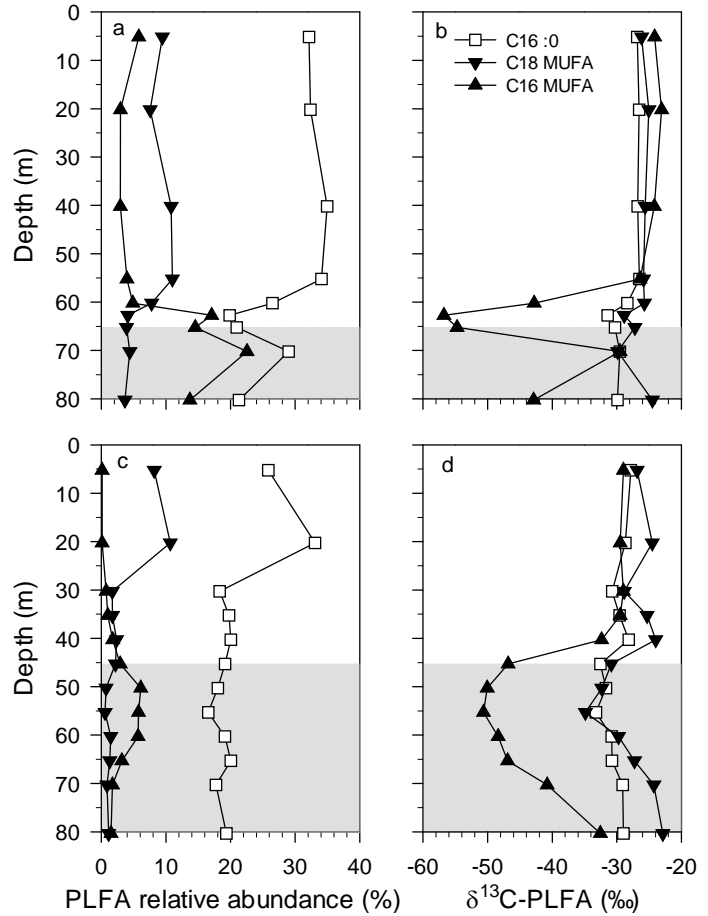

Figure 3. Vertical profiles of the relative abundance of phospholipid fatty acids (PLFAs, \%) and their respective carbon isotopic signature $\left(\delta^{13}\right.$ C-PLFAs, $\%$ o $)$ in $(\mathbf{a}, \mathbf{b})$ the southern basin in September 2012 (dry season) and (c, d) in the northern basin in February 2012. Error bars representing standard deviation of replicates were smaller than the data point size. The grey zone corresponds to waters with dissolved $\mathrm{O}_{2}$ concentration $<3 \mu \mathrm{mol} \mathrm{L}{ }^{-1}$.

described by the following equation (rearranged from Eq. 11 in Coleman et al., 1981):

$$
\begin{gathered}
\ln (1-f)=\ln \left(\left(\delta^{13} \mathrm{CH}_{4 \mathrm{t}}+1000\right) /\right. \\
\left.\left(\delta^{13} \mathrm{CH}_{4 \mathrm{~b}}+1000\right)\right) /((1 / \alpha)-1),
\end{gathered}
$$

where $f$ is the fraction of $\mathrm{CH}_{4}$ oxidized within the depth interval, $\delta^{13} \mathrm{CH}_{4 \mathrm{~b}}$ and $\delta^{13} \mathrm{CH}_{4 \mathrm{t}}$ are the $\delta^{13} \mathrm{C}$ values of $\mathrm{CH}_{4}$ at the bottom and the top of the depth interval, respectively, and $\alpha$ is the isotope fractionation factor for $\mathrm{CH}_{4}$ oxidation estimated in Lake Kivu in September $2012(\alpha=1.016 \pm 0.007)$. Based on this equation and using a range of isotope fractionation factors (from 1.009 to 1.023 ), we can estimate that 51$84 \%$ of the upward flux of $\mathrm{CH}_{4}$ was microbially oxidized within a $10 \mathrm{~m}$ depth interval in the oxycline $(60-70 \mathrm{~m})$ in the southern basin during the dry season (September 2012). Similarly, 51-84\% of the $\mathrm{CH}_{4}$ flux was oxidized between 50 and $55 \mathrm{~m}$ in the northern basin during the dry season, and 58-89\% of the $\mathrm{CH}_{4}$ flux was oxidized within a wider depth interval $(45-70 \mathrm{~m})$ during the rainy season (February 2012). The relatively wide range of the estimated percentage of $\mathrm{CH}_{4}$ flux oxidized is due to the uncertainty on the isotope fractionation factor. Nevertheless, these calculations illustrate clearly

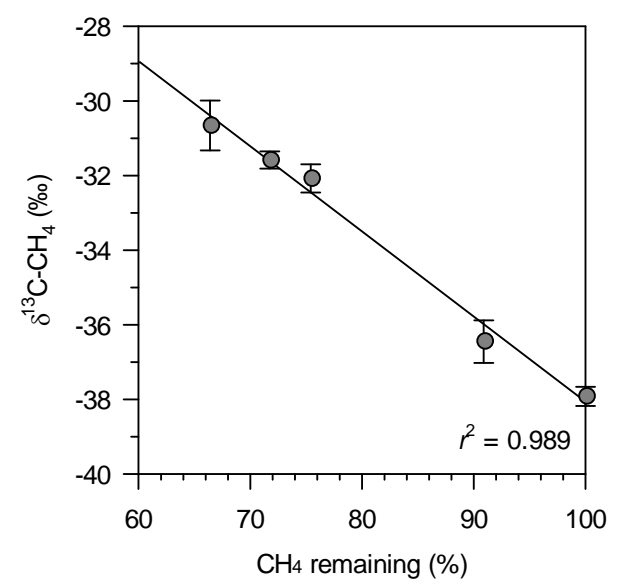

Figure 4. Example $(62.5 \mathrm{~m})$ of relationship between the $\delta^{13} \mathrm{C}-\mathrm{CH}_{4}$ and the fraction of $\mathrm{CH}_{4}$ remaining in the bottles during the incubation $(\%)$ to determine the isotope fractionation factor carried out in September 2012 in the southern basin. Data points were gathered at a $24 \mathrm{~h}$ interval. Symbols are the mean of duplicates; error bars represent standard deviation of duplicates when higher than data point size.

the importance of microbial $\mathrm{CH}_{4}$ oxidation processes in preventing $\mathrm{CH}_{4}$ to reach the surface waters of the lake.

The theoretical $\delta^{13} \mathrm{C}$ signature of methanotrophs can be estimated at each depth from $\delta^{13} \mathrm{C}_{-} \mathrm{CH}_{4}$ values and the experimental isotope fractionation factor $(\alpha$, ranged between 1.009-1023). Applying a simple isotope mixing model with the $\delta^{13} \mathrm{C}$ signature of methanotrophs as an end-member and the $\delta{ }^{13} \mathrm{C}$-POC in the surface $(5 \mathrm{~m})$ as an organic matter endmember which forms as sediment, it is possible to estimate the contribution of $\mathrm{CH}_{4}$-derived $\mathrm{C}$ to the $\mathrm{POC}$ pool. Indeed, the contribution of $\mathrm{CH}_{4}$-derived $\mathrm{C}$ appeared to be substantial at the bottom of the mixolimnion. In September 2012 in the southern basin, 32-44\% of the depth-integrated POC pool in the oxycline (between 60 and $70 \mathrm{~m}$ ) originated from $\mathrm{CH}_{4}$ incorporation, with a local maximum at the transition between oxic and $\mathrm{O}_{2}$-depleted waters $(65 \mathrm{~m}, 44-54 \%)$. In the northern basin, $13-16 \%$ of the POC in the oxycline (between 50 and $60 \mathrm{~m}$ ) derived from $\mathrm{CH}_{4}$. However, the contribution of $\mathrm{CH}_{4}$ to the $\mathrm{POC}$ pool was relatively lower during the rainy season, as only $4-6 \%$ of the POC in the $50-70 \mathrm{~m}$ depth interval, below the oxycline, had been fixed by methanotrophic organisms in the northern basin in February 2012 (local maximum slightly below the oxycline at $50 \mathrm{~m}, 8-10 \%$ ).

${ }^{13} \mathrm{CH}_{4}$ tracer experiments allowed estimation of the net MBP and the MBGE. Whatever the season, the highest MBP $\left(0.8-7.2 \mu \mathrm{mol} \mathrm{C} \mathrm{L}^{-1} \mathrm{~d}^{-1}\right)$ rates were found near the transition between oxic and $\mathrm{O}_{2}$-depleted waters. Hence, $\mathrm{CH}_{4}$ oxidation in Lake Kivu seems to be mainly driven by oxic processes. Furthermore, maximal MBP rates were observed where the in situ $\mathrm{CH}_{4}: \mathrm{O}_{2}$ ratio ranged between 0.1 and 10 (molar units, Fig. 6), encompassing the stoichiometric $\mathrm{CH}_{4}: \mathrm{O}_{2}$ ratio for aerobic microbial $\mathrm{CH}_{4}$ oxidation $(0.5)$ and 

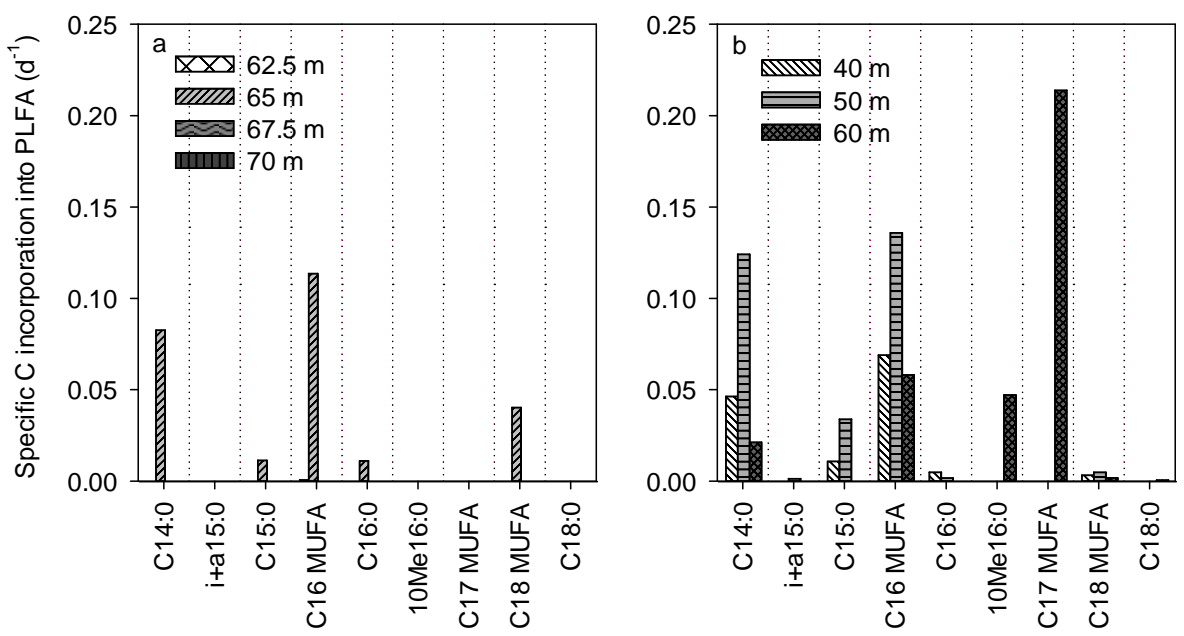

Figure 5. Specific $\mathrm{CH}_{4}$-derived $\mathrm{C}$ incorporation pattern into phospholipid fatty acids (PLFAs; incorporation rates of C into PLFAs normalized on PLFA concentration, $\mathrm{d}^{-1}$ ) in (a) September 2012 (dry season) in the southern basin and (b) in February 2012 (rainy season) in the northern basin. Dissolved $\mathrm{O}_{2}$ concentration was lower than $3 \mu \mathrm{mol} \mathrm{L}^{-1}$ at 67.5 and $70 \mathrm{~m}(\mathbf{a})$, and 50 and $60 \mathrm{~m}$ (b).

the optimal ratio estimated in the culture experiments $(0.9$, Amaral and Knowles, 1995). This relationship highlights the importance of the regulation of aerobic methanotrophic production by both $\mathrm{CH}_{4}$ and $\mathrm{O}_{2}$ availability. Vertically integrated over the water column, the MBP was estimated at $29.5 \mathrm{mmol} \mathrm{m}^{-2} \mathrm{~d}^{-1}$ during the rainy season in the northern basin, and 28.6 and $8.2 \mathrm{mmol} \mathrm{m}^{-2} \mathrm{~d}^{-1}$ during the dry season in the southern basin and the northern basin, respectively. These rates are comparable to the gross $\mathrm{CH}_{4}$ oxidation rate reported earlier by Jannasch (1975) in Lake Kivu $\left(7.2 \mathrm{mmol} \mathrm{m}^{-2} \mathrm{~d}^{-1}\right)$ and the upward $\mathrm{CH}_{4}$ flux recently estimated $\left(9.38 \mathrm{mmol} \mathrm{m}^{-2} \mathrm{~d}^{-1}\right)$ by Pasche et al. (2009). Areal MBP in Lake Kivu is equivalent to $16-60 \%$ of the mean annual phytoplankton primary production $\left(49 \mathrm{mmol} \mathrm{m}^{-2} \mathrm{~d}^{-1}\right.$, Darchambeau et al., 2014), suggesting that biomass production by methanotrophs has the potential to sustain a significant fraction of the pelagic food web. For example, it has been shown that cyclopoid copepods (mesozooplankton) of Lake Kivu escape visual predators by migrating below the euphotic zone, sometimes down to $\mathrm{O}_{2}$-depleted waters (Isumbisho et al., 2006), where they might feed on $\mathrm{CH}_{4}$ derived $\mathrm{C}$ sources.

The relative contribution of MBP to the autochtonous production in Lake Kivu was distinctly higher than those reported in three Swedish lakes during summer, where MBP was equivalent to 0.3 and $7.0 \%$ of the phytoplankton production (Bastviken et al., 2003). This was unrelated to the phytoplankton production rates in the Swedish lakes that ranged between 7 and $83 \mathrm{mmol} \mathrm{m}^{-2} \mathrm{~d}^{-1}$ and encompassed the average phytoplankton production value in Lake Kivu $\left(49 \mathrm{mmol} \mathrm{m}^{-2} \mathrm{~d}^{-1}\right)$. The MBP rates in the Swedish lakes (based on ${ }^{14} \mathrm{C}$ incubations) were, however, distinctly lower than in Lake Kivu, ranging between 0.3 and $1.8 \mathrm{mmol} \mathrm{m}^{-2} \mathrm{~d}^{-1}$. This difference is probably related to

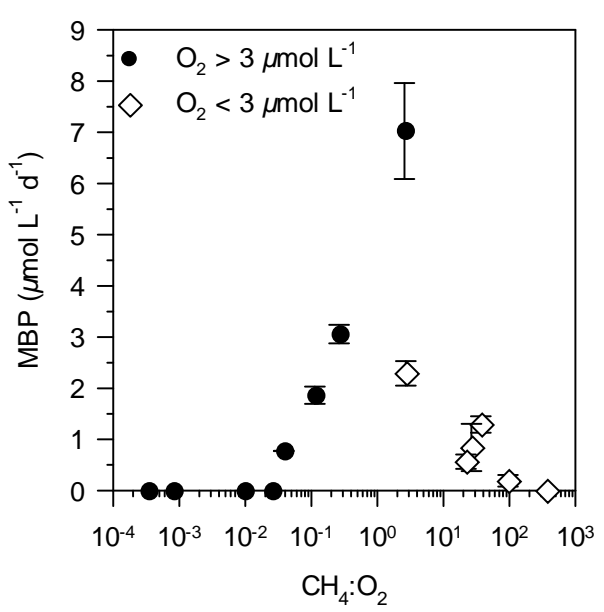

Figure 6. In Lake Kivu, relationship between the methanotrophic

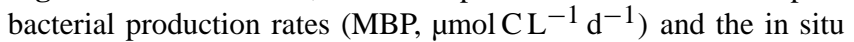
$\mathrm{CH}_{4}: \mathrm{O}_{2}$ molar ratio. Symbols represent mean MBP values, vertical error bars represent standard deviation of replicates. The $\mathrm{CH}_{4}: \mathrm{O}_{2}$ ratio was calculated with an $\mathrm{O}_{2}$ concentration value of $3 \mu \mathrm{mol} \mathrm{L}-1$ when observed in situ values were below the detection limit of the sensor $(3 \mu \mathrm{mol} \mathrm{L}-1)$.

the high $\mathrm{CH}_{4}$ concentrations at the transition between oxic and $\mathrm{O}_{2}$-depleted waters in Lake Kivu, as MBP peaked in the Swedish lakes at $\mathrm{CH}_{4}$ concentrations $<100 \mu \mathrm{mol} \mathrm{L}^{-1}$, while MBP peaked in Lake Kivu at $\mathrm{CH}_{4}$ concentrations one to two orders of magnitude higher. Kankaala et al. (2013) reported seasonally resolved (for the ice-free period) MBP in five small $\left(0.004\right.$ to $\left.13.4 \mathrm{~km}^{2}\right)$ boreal humic lakes (with dissolved organic $\mathrm{C}$ concentrations ranging between 7 and $24 \mathrm{mg} \mathrm{C} \mathrm{L}^{-1}$ ) in southern Finland. In these lakes, phytoplankton production and MBP were highly variable, ranging 
between 5 and $50 \mathrm{mmol} \mathrm{m}^{-2} \mathrm{~d}^{-1}$ and $<0.2 \mathrm{mmol} \mathrm{C} \mathrm{m}^{-2} \mathrm{~d}^{-1}$ and $41 \mathrm{mmol} \mathrm{m}^{-2} \mathrm{~d}^{-1}$, respectively. MBP was significantly higher in the two smallest lakes $\left(0.004-0.008 \mathrm{~km}^{2}\right)$, characterized by high $\mathrm{CH}_{4}$ concentrations $\left(<750 \mu \mathrm{mol} \mathrm{L}^{-1}\right)$ and permanent anoxia throughout the year in bottom waters. Considering a MBGE of $25 \%$, their MBP estimates corresponded to a highly variable percentage of phytoplankton production, between 35 and $100 \%$ in the two smallest lakes, and between 0.4 and $5.0 \%$ in the three larger lakes $(0.04$ to $13.4 \mathrm{~km}^{2}$ ), and therefore they proposed that the relative contribution of methanotrophic bacteria to the total autotrophic production in a lake is related to its size (Kankaala et al., 2013). However, the results reported for the large $\left(2370 \mathrm{~km}^{2}\right)$ Lake Kivu do not fit with this general pattern, probably because of the permanent and strong stratification of its water column that on one hand promotes a long residence time of deep waters and the accumulation of $\mathrm{CH}_{4}$, and on the other hand leads to very slow upward diffusion of solutes, promoting the removal of $\mathrm{CH}_{4}$ by bacterial oxidation as it diffuses to the surface.

The MBGE found during this study was variable (2-50\%), but within the range of reported values in fresh waters (15$80 \%$, King, 1992; 6-72\%, Bastviken et al., 2003). MBGE was negatively related to the $\mathrm{CH}_{4}: \mathrm{O}_{2}$ ratio (Fig. 7); i.e. a smaller fraction of the oxidized $\mathrm{CH}_{4}$ was incorporated into the biomass at the bottom of the oxycline, where $\mathrm{O}_{2}$ availability was relatively limited compared to $\mathrm{CH}_{4}$. It has been recently suggested that under $\mathrm{O}_{2}$-limiting conditions, methanotrophic bacteria are able to generate energy (adenosine triphosphate) by fermentation of formaldehyde (Kalyuzhnaya et al., 2013), the key intermediate in the oxidation of $\mathrm{CH}_{4}$. This $\mathrm{CH}_{4}$-based fermentation pathway would lead to the production of excreted organic acids (lactate, formate, ...) from $\mathrm{CH}_{4}$-derived $\mathrm{C}$ instead of converting $\mathrm{CH}_{4}$ into cellular biomass. If the metabolic abilities for this process are ubiquitous in methanotrophic organisms, it may potentially occur within the water column of Lake Kivu, at the bottom of the oxycline or in micro-oxic zone, as suggested by the low MBGE values found at high $\mathrm{CH}_{4}: \mathrm{O}_{2}$ molar ratio.

Almost all known aerobic methanotrophic bacteria are phylogenetically affiliated to Proteobacteria, belonging either to the Gammaproteobacteria (also referred to type I methanotrophs) or Alphaproteobacteria (type II methanotrophs) classes (Hanson and Hanson, 1996). The two distinct groups differ in some important physiological characteristics. Notably, they use different $\mathrm{C}$ fixation pathway (ribulose monophosphate for type I; the serine pathway for type II) and possess different patterns of PLFAs. C16 MUFA are especially abundant in the type I methanotrophs while the type II methanotrophs contain mainly C18 MUFA (Le Bodelier et al., 2009). Therefore, the much larger ${ }^{13} \mathrm{C}$ depletion of C16 MUFA than C18 MUFA and the strong labelling of C16 MUFA during the incubation with ${ }^{13} \mathrm{C}_{-} \mathrm{CH}_{4}$ indicate that the aerobic methanotrophic community was dominated by type I methanotrophs in the water column during this study. In

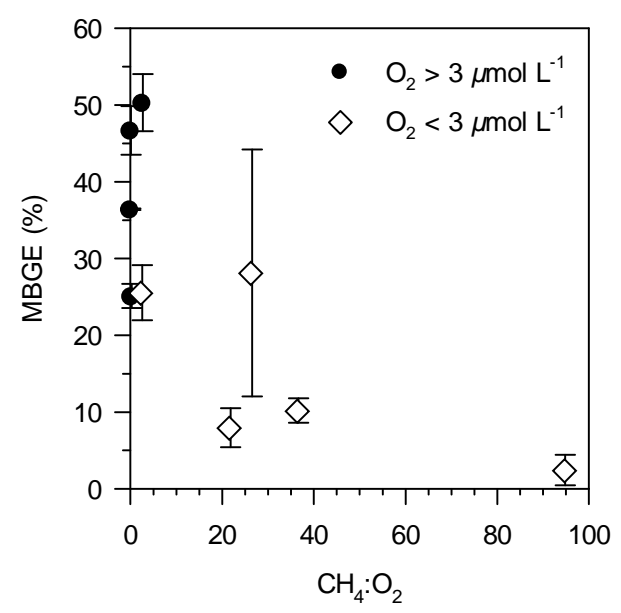

Figure 7. In Lake Kivu, relationship between the methanotrophic bacterial growth efficiency and the in situ $\mathrm{CH}_{4}: \mathrm{O}_{2}$ molar ratio. Symbols represent mean MBGE values, vertical error bars represent standard deviation of replicates. The $\mathrm{CH}_{4}: \mathrm{O}_{2}$ ratio was calculated with an $\mathrm{O}_{2}$ concentration value of $3 \mu \mathrm{mol} \mathrm{L}{ }^{-1}$ when observed in situ values were below the detection limit of the sensor $\left(3 \mu \mathrm{mol} \mathrm{L}^{-1}\right)$.

contrast, Type II methanotrophs did not appear to contribute much to the overall $\mathrm{CH}_{4}$ oxidation in Lake Kivu, in good agreement with the results of Pasche et al. (2011). Nevertheless, in February 2012 the C16 MUFA appeared to be strongly depleted in ${ }^{13} \mathrm{C}$ below the transition between oxic and $\mathrm{O}_{2}$-depleted waters (Fig. 3). Strong ${ }^{13} \mathrm{C}$-depletion of bacterial lipid markers for aerobic methanotrophic bacteria in $\mathrm{O}_{2}$-depleted waters has also been reported in the Black Sea (Schubert et al., 2006) and in Lake Lugano (Blees et al., 2014). The presence of methanotrophic bacterial biomass below the oxycline could simply result from gravity-driven physical particle transport from oxic waters, but it has been also demonstrated that some aerobic methanotrophs are able to persist under low oxygen conditions in a reversible state of reduced metabolic activity (Roslev and King, 1995). In contrast, the recovery of these aerobic methanotrophs after $\mathrm{CH}_{4}$ deprivation under oxic conditions is less successful because of a significant degradation of cell proteins (Roslev and King, 1995). Blees et al. (2014) suggested that this physiological preference for $\mathrm{O}_{2}$ starvation than $\mathrm{CH}_{4}$ starvation under oxic conditions would drive aerobic methanotrophs towards the $\mathrm{O}_{2}$-depleted part of the oxygen continuum. This concept seems particularly important in tropical lakes because the thermal stratification of the water column is usually very dynamic in these systems due to the small temperature gradient, allowing episodic, yet frequent, $\mathrm{O}_{2}$ intrusion events into deeper waters. Aerobic methanotrophs in dormancy would recover quickly after the episodical $\mathrm{O}_{2}$ injection, and resume rapidly micro aerobic $\mathrm{CH}_{4}$ oxidation (Blees et al., 2014).

The dominance of type I over type II methanotrophs has been frequently reported in various stratified freshwater (Sundh et al., 2005; Blees et al., 2014) or marine envi- 
ronments (Schubert et al., 2006; Schmale et al., 2012), but this recurrent observation is still difficult to explain. In a recent review, Ho et al. (2013) attempted to classify several genera of methanotrophs according to their life strategies, using the competitor/stress-tolerator/ruderal functional classification framework (Grime, 1977). Since type I methanotrophs dominate the active community in many environments and are known to respond rapidly to substrate availability, they classified them as competitors, or competitor ruderals. In contrast, they proposed that type II members would be more tolerant to environmental stress, and thus classified them as stress tolerators, or stress-tolerator ruderals. Relatively large availability of $\mathrm{CH}_{4}$ and $\mathrm{O}_{2}\left(\mathrm{O}_{2}: \mathrm{CH}_{4}\right.$ ratio close to 1, Figs. 2 and 6 ) at the bottom of the oxycline of Lake Kivu is a favourable environment for the competitorruderal bacterial communities that could explain the dominance of type I methanotrophs over type II methanotrophs in this lake.

A significant MBP rate $\left(1.3 \mu \mathrm{mol} \mathrm{L}^{-1} \mathrm{~d}^{-1}\right)$ was measured in $\mathrm{O}_{2}$-depleted waters $(<3 \mu \mathrm{mol} \mathrm{L}-1)$ at $60 \mathrm{~m}$ during the rainy season (February 2012). Moreover, the PLFA labelling pattern was drastically different, with a more important specific ${ }^{13} \mathrm{C}$ incorporation into 10Me16:0 and C17 MUFA instead of the C16 MUFA, relative to their concentrations. This different labelling pattern suggests that a different population of methanotrophs was active in $\mathrm{CH}_{4}$ oxidation deeper in the water column. Archaea lack ester-linked fatty acids in their membrane and are therefore undetectable in PLFA analysis. However 10Me16: 0 and C17 MUFA are known to be especially abundant in sulphate-reducing bacteria (Macalady et al., 2000; Boschker and Middelburg, 2002), one of the syntrophic partner of anaerobic $\mathrm{CH}_{4}$ oxidizing archaea (Knittel and Boetius, 2009). Hence, the specific labelling of 10Me16:0 and C17 MUFA in $\mathrm{O}_{2}$-depleted waters could indicates that a fraction of the upward flux of $\mathrm{CH}_{4}$ was oxidized syntrophically by an archaea/bacteria consortium, and might support the hypothesis that the bacterial partner grow on $\mathrm{CH}_{4}$-derived carbon source supplied by anaerobic methane oxidizers within the consortium, as already suggested by the results of an in vitro labelling $\left({ }^{13} \mathrm{CH}_{4}\right)$ study (Blumenberg et al., 2005). However, our data does not necessary imply that anaerobic methane oxidation would be coupled with $\mathrm{SO}_{4}^{2-}$ reduction, as some sulphate-reducing bacteria have been also found to be able to reduce iron (Coleman et al., 1993). Furthermore, the phylogenetic resolution of SIP-PLFA analyses in rather low (Uhlík et al., 2009), and recent studies showed that anaerobic methane oxidation could be carried out syntrophically by consortium between methanotrophic archaea and denitrifying bacteria (Raghoebarsing et al., 2006), or between methanotrophic archaea and manganese reducing bacteria (Beal et al., 2009). Further investigations would be needed to address more accurately which is the electron acceptors coupled to anaerobic $\mathrm{CH}_{4}$ oxidation.

\section{Conclusions}

We provide conclusive evidences on the occurrence of $\mathrm{CH}_{4}$ oxidation in the oxycline of Lake Kivu using stable isotopic characterization of a suite of carbon pools $\left(\mathrm{CH}_{4}, \mathrm{POC}\right.$, PLFAs) as well as rate measurements (MBP). Vertically integrated MBP ranged between 8 and $29 \mathrm{mmol} \mathrm{m}^{-2} \mathrm{~d}^{-1}$, and was higher than previously reported in other lakes (Bastvinken et al., 2003; Kankaala et al., 2013). MBP was equivalent to $16-60 \%$ of the average annual phytoplankton primary production, a fraction distinctly higher than previously reported in other lakes, usually $<10 \%$ (Bastvinken et al., 2003; Kankaala et al., 2006). Hence, methanotrophic bacteria could potentially sustain a significant fraction of the pelagic food web in this oligotrophic $\mathrm{CH}_{4}$-rich lake. Lake Kivu ranks globally among the lakes with the lowest $\mathrm{CH}_{4}$ emissions into the atmosphere (Borges et al., 2011), despite the huge amount of $\mathrm{CH}_{4}$ dissolved in its deep waters and a relatively high upward flux of $\mathrm{CH}_{4}$ to the mixed layer (9.38 $\mathrm{mmol} \mathrm{m}^{-2} \mathrm{~d}^{-1}$, Pasche et al., 2009). This apparent paradox is linked to its strong meromictic nature that on one hand promotes a long residence time of deep waters and the accumulation of $\mathrm{CH}_{4}$, and on the other hand leads to very slow upward diffusion of solutes, promoting the removal of $\mathrm{CH}_{4}$ by microbial oxidation as it diffuses to the surface.

Acknowledgements. We are grateful to Boniface Kaningini, Pascal Isumbisho and Pascal Masilya (Institut Supérieur Pédagogique, Bukavu, DRC), Laetitia Nyinawamwiza (National University of Rwanda, Rwanda), for logistic support during the cruises, to Laetitia Montante and to Stephan Hoornaert for help during fieldwork and during laboratory analysis, and to Christophe Rabouille (associate editor), Martin Schmid, and two anonymous reviewers for providing constructive comments on an earlier version of this manuscript. This work was funded by the EAGLES (East African great lake ecosystem sensitivity to changes, SD/AR/02A) project from the Belgian Federal Science Policy Office (BELSPO, Belgium), the CAKI (Cycle du carbone et des nutriments au Lac Kivu, contract 2.4.598.07) and MICKI (Microbial diversity and processes in Lake Kivu, contract 2.4.515.11) projects from the Fonds National de la Recherche Scientifique (FNRS, Belgium), and contributes to the European Research Council (ERC) starting grant project AFRIVAL (African river basins: catchment-scale carbon fluxes and transformations, 240002). A.V. Borges is a senior research associate at the FNRS.

Edited by: C. Rabouille

\section{References}

Amaral, J. A. and Knowles, R.: Growth of methanotrophs in methane and oxygen counter gradients, FEMS Microbiol. Lett., 126, 215-220, 1995.

Bastviken, D., Ejlertsson, J., Sundh, I., and Tranvik, L.: Methane as a source of carbon and energy for lake pelagic food webs, Ecology, 84, 969-981, 2003. 
Bastviken, D., Tranvik, L. J., Downing, J. A., Crill, P. M., and Enrich-Prast, A.: Freshwater methane emissions offset the continental carbon sink, Science, 331, 50-50, 2011.

Beal, E. J., House, C. H., and Orphan, V. J. Manganese-and irondependent marine methane oxidation, Science, 325, 184-187, 2009.

Blees, J., Niemann, H., Wenk, C. B., Zopfi, J., Schubert, C. J., Kirf, M. K., Veronesi, M. L., Hitz, C., and Lehmann, M. F.: Micro-aerobic bacterial methane oxidation in the chemocline and anoxic water column of deep south-Alpine Lake Lugano (Switzerland), Limnol. Oceanogr., 59, 311-324, 2014.

Blumenberg, M., Seifert, R., Nauhaus, K., Pape, T., and Michaelis, W.: In vitro study of lipid biosynthesis in an anaerobically methane-oxidizing microbial mat, Appl. Environ. Microb., 71, 4345-4351, 2005.

Boetius, A., Ravenschlag, K., Schubert, C. J., Rickert, D., Widdel, F., Gieseke, A., Amann, R., Jørgensen, B. B., Witte, U., and Pfannkuche, O.: A marine microbial consortium apparently mediating anaerobic oxidation of methane, Nature, 407, 623-626, 2000.

Borges, A. V., Abril, G., Delille, B., Descy, J. P., and Darchambeau, F.: Diffusive methane emissions to the atmosphere from Lake Kivu (Eastern Africa), J. Geophys. Res., 116, G03032, doi:10.1029/2011JG001673, 2011.

Boschker, H. T. S.: Linking microbial community structure and functioning: stable isotope (13C) labeling in combination with PLFA analysis, in: Molecular Microbial Ecology Manual II, edited by: Kowalchuk, G. A., de Bruijn, F. J., Head, I. M., Akkermans, A. D., and van Elsas, J. D., Kluwer Academic Publishers, the Netherlands, 1673-1688, 2004.

Boschker, H. T. S. and Middelburg, J. J.: Stable isotopes and biomarkers in microbial ecology, FEMS Microbiol. Ecol., 40, 85-95, 2002.

Coleman, D. D., Risatti, J. B., and Schoell, M.: Fractionation of carbon and hydrogen by methane-oxidizing bacteria, Geochim. Cosmochim. Ac., 45, 1033-1037, 1981.

Coleman, M. L., Hedrick, D. B., Lovley, D. R., White, D. C., and Pye, K.: Reduction of Fe(III) in sediments by sulphate-reducing bacteria, Nature, 361, 436-438, 1993.

Damas, H.: La stratification thermique et chimique des lacs Kivu, Edouard et Ndalaga (Congo Belge), Verhandlungen der Internationalen Vereinigung für Theoretische und Angewandte Limnologie, Schweizerbart science publishers, Stuttgart, 8, 51-68, 1937.

Darchambeau, F., Sarmento, H., and Descy, J.-P.: Primary production in a tropical large lake: The role of phytoplankton composition, Sci. Total Environ., 473, 178-188, 2014.

Degens, E. T., vos Herzes, R. P., Wosg, H.-K., Deuser, W. G., and Jannasch, H. W.: Lake Kivu: Structure, chemistry and biology of an East African rift lake, Geologische Rundschau, 62, 245-277, 1973.

Denman, K. L., Brasseur, G., Chidthaisong, A., Ciais, P., Cox, P. M., Dickinson, R. E., Hauglustaine, D., Heinze, C., Holland, E., Jacob, D., Lohmann, U., Ramachandran, S., da Silva Dias, P. L., Wofsy, S. C., and Zhang, X.: Couplings between changes in the climate system and biogeochemistry, in: Climate Change 2007: The Physical Science Basis, Contribution of Working Group I to the Fourth Assessment Report of the Intergovernmental Panel on Climate Change, edited by: Solomon, S., Qin, D., Manning,
M., Chen, Z., Marquis, M., Averyt, K. B., Tignor, M., and Miller, H. L., Cambridge University Press, Cambridge, United Kingdom and New York, NY, USA, 499-587, 2007.

Forster, P., Ramaswamy, V., Artaxo, P., Berntsen, T., Betts, R., Fahey, D. W., Haywood, J., Lean, J., Lowe, D. C., Myhre, G., Nganga, J., Prinn, R., Raga, G., Schulz, M., and Van Dorland, R.: Changes in atmospheric constituents and in radiative forcing, in: Climate Change 2007: The Physical Science Basis, Contribution of Working Group I to the Fourth Assessment Report of the Intergovernmental Panel on Climate Change, edited by: Solomon, S., Qin, D., Manning, M., Chen, Z., Marquis, M., Averyt, K. B., Tignor, M., and Miller, H. L., Cambridge University Press, Cambridge, United Kingdom and New York, NY, USA, 499-587, 129-234, 2007.

Grime, J. P.: Evidence for the existence of three primary strategies in plants and its relevance to ecological and evolutionary theory, Am. Nat., 111, 1169-1194, 1977.

Hama, T., Miyazaki, T., Ogawa, Y., Iwakuma, T., Takahashi, M., Otsuki, A., and Ichimura, S.: Measurement of photosynthetic production of a marine phytoplankton population using a stable ${ }^{13} \mathrm{C}$ isotope, Mar. Biol., 73, 31-36, 1983.

Hanson, R. S. and Hanson, T. E.: Methanotrophic bacteria, Microbiol. Rev., 60, 439-471, 1996.

Ho, A., Kerckhof, F. M., Luke, C., Reim, A., Krause, S., Boon, N., and Le Bodelier, P. L.: Conceptualizing functional traits and ecological characteristics of methane-oxidizing bacteria as life strategies, Environmental Microbiology Reports, 5, 335-345, 2013.

Isumbisho, M., Sarmento, H., Kaningini, B., Micha, J. C., and Descy, J-P.: Zooplankton of Lake Kivu, East Africa, half a century after the Tanganyika sardine introduction, J. Plankton Res., 28, 971-989, 2006.

Jannasch, H. W.: Methane oxidation in Lake Kivu (central Africa), Limnolo. Oceanogr., 20, 860-864, 1975.

Jones, R. I. and Grey, J.: Biogenic methane in freshwater food webs, Freshwater Biology, 56, 213-229, 2011.

Kalyuzhnaya, M. G., Yang, S., Rozova, O. N., Smalley, N. E., Clubb, J., Lamb, A., Nagana, G. A., Gowda, D., Raftery, D., Fu, Y., Bringel, F., Vuilleumier, S., Beck, D. A. C., Trosenko, Y. A., Khmelenina, V. N., and Lidstrom, M. E.: Highly efficient methane biocatalysis revealed in a methanotrophic bacterium, Nature communications, 4, 2785, doi:10.1038/ncomms3785, 2013.

Kankaala, P., Taipale, S., Grey, J., Sonninon, E., Arvola, L., and Jones, R. I.: Experimental $\delta^{13} \mathrm{C}$ evidence for a contribution of methane to pelagic food webs in lakes, Limnol. Oceanogr., 51, 2821-2827, 2006.

Kankaala, P., Bellido, J. L., Ojala, A., Tulonen, T., and Jones, R. I.: Variable production by different pelagic energy mobilizers in boreal lakes, Ecosystems, 16, 1152-1164, 2013.

King, G. M.: Ecological aspects of methane oxidation, a key determinant of global methane dynamics, in: Advances in microbial ecology, edited by: Marshall, K. C., Plenum Press, New York, USA, 431-468, 1992.

Kirschke, S., Bousquet, P., Ciais, P., Saunois, M., Canadell, J. G., Dlugokencky, E. J., Bergamaschi, P., Bergmann, D., Blake, D. R., Bruhwiler, L., Cameron-Smith, P., Castaldi, S., Chevallier, F. Feng, L., Fraser, A., Heimann, M., Hodson, E. L., Houweling, S., Josse, B., Fraser, P. J., Krummel, P. B., Lamarque, J.- 
F., Langenfelds, R. L., Le Quéré, C., Naik, V., O’Doherty, S., Palmer, P. I., Pison, I., Plummer, D., Poulter, B., Prinn, R. G., Rigby, M., Ringeval, B., Santini, M., Schmidt, M., Shindell, D. T., Simpson, I. J., Spahni, R., Steele, L. P., Strode, S. A., Sudo, K., Szopa, S., van der Werf, G., Voulgarakis, A., van Weele, M., Weiss, R. F., Williams J. E., and Zeng G.: Three decades of global methane sources and sinks, Nat. Geosci., 6, 813-823, doi:10.1038/NGEO1955, 2013.

Knitell, K. and Boetius, A.: Anaerobic oxidation of methane: progress with an unknown process, Annu. Rev. Microbiol., 63, 311-334, 2009.

Le Bodelier, P. L., Gillisen, M. J. B., Hordijk, K., Damsté, J. S. S., Rijpstra, W. I. C., Geenevasen, J. A., and Dunfield, P. F.: A reanalysis of phospholipid fatty acids as ecological biomarkers for methanotrophic bacteria, The ISME journal, 3, 606-617, 2009.

Lehmann, M. F., Bernasconi, S. M., McKenzie, J. A., Barbieri, A., Simona, M., and Veronesi, M.: Seasonal variation of the $\delta^{13} \mathrm{C}$ and $\delta^{15} \mathrm{~N}$ of particulate and dissolved carbon and nitrogen in Lake Lugano: Constraints on biogeochemical cycling in a eutrophic lake, Limnol. Oceanogr., 49, 415-429, 2004.

Macalady, J. L., Mack, E. E., Nelson, D. C., and Scow, K. M.: Sediment microbial community structure and mercury methylation in mercury-polluted Clear Lake, California, Appl. Environ. Microbiol., 66, 1479-1488, 2000.

Pasche, N., Dinkel, C., Müller, B., Schmid, M., Wüest, A., and Wehrli, B.: Physical and bio-geochemical limits to internal nutrient loading of meromictic Lake Kivu, Limnol. Oceanogr., 54, 1863-1873, 2009.

Pasche, N., Schmid, M., Vazquez, F., Schubert, C. J., Wüest, A., Kessler, J. D., Pack, M. A., Reeburgh, W. S., and Bürgmann, H.: Methane sources and sinks in Lake Kivu, J. Geophys. Res., 116, G03006, doi:10.1029/2011JG001690, 2011.

Raghoebarsing, A. A, Pol, A., van de Pas-Schoonen, K. T., Smolders, A. J. P., Ettwig, K. F., Rijpstra, W. I. C., Schouten, S., Sinninghe Damsté, J. S., Op den Camp, H. J. M., Jetten, M. S. M., and Strous, M.: A microbial consortium couples anaerobic methane oxidation to denitrification, Nature, 440, 918-921, 2006.

Roslev, P. and King, G. M.: Aerobic and anaerobic starvation metabolism in methanotrophic bacteria, Appl. Environ. Microbiol., 61, 1563-1570, 1995.

Rudd, J. W., Hamilton, R. D., and Campbell, N. E. R.: Measurement of microbial oxidation of methane in lake water, Limnol. Oceanogr., 19, 519-524, 1974.
Sanseverino, A. M., Bastviken, D., Sundh, I., Pickova, J., and Enrich-Prast, A.: Methane Carbon Supports Aquatic Food Webs to the Fish Level, PLoS ONE, 7, e42723, doi:10.1371/journal.pone.0042723, 2012.

Sarmento, H., Isumbisho, M., and Descy, J.-P.: Phytoplankton ecology of Lake Kivu (Eastern Africa), J. Plankton Res., 28, 815829, 2006.

Schmale, O., Blumenberg, M., Kießlich, K., Jakobs, G., Berndmeyer, C., Labrenz, M., Thiel, V., and Rehder, G.: Aerobic methanotrophy within the pelagic redox-zone of the Gotland Deep (central Baltic Sea), Biogeosciences, 9, 4969-4977, doi:10.5194/bg-9-4969-2012, 2012.

Schmid, M., Halbwachs, M., Wehrli, B., and Wüest, A.: Weak mixing in Lake Kivu: new insights indicate increasing risk of uncontrolled gas eruption, Geochem. Geophys. Geosys., 6, Q07009, doi:10.1029/2004GC000892, 2005.

Schubert, C. J., Coolen, M. J., Neretin, L. N., Schippers, A., Abbas, B., Durisch-Kaiser, and Kuypers, M. M.: Aerobic and anaerobic methanotrophs in the Black Sea water column, Environ. Microbiol., 8, 1844-1856, 2006.

Sundh, I., Bastviken, D., and Tranvik, L. J.: Abundance, activity, and community structure of pelagic methane-oxidizing bacteria in temperate lakes, Appl. Environ. Microbiol., 71, 6746-6752, 2005.

Thiery, W., Martynov, A., Darchambeau, F., Descy, J.-P., Plisnier, P.-D., Sushama, L., and van Lipzig, N. P. M.: Understanding the performance of the FLake model over two African Great Lakes, Geosci. Model Dev., 7, 317-337, doi:10.5194/gmd-7-317-2014, 2014.

Uhlík, O., Jecná, K., Leigh, M. B., Macková, M., and Macek, T.: DNA-based stable isotope probing: a link between community structure and function, Sci. Total Environ., 407, 3611-3619, 2009.

Weiss, R. F.: Determinations of carbon dioxide and methane by dual catalyst flame ionization chromatography and nitrous oxide by electron capture chromatography, J. Chromatogr. Sci., 19, 611616, 1981.

Yamamoto, S., Alcauskas, J. B., and Crozier, T. E.: Solubility of methane in distilled water and seawater, J. Chem. Eng., 21, 7880, 1976.

Zigah, P. K., Oswald, K., Brand, A., Dinkel, C., Wehrli, B., and Schubert, C.: Methane oxidation pathways and associated methanotrophic communities in the water column of a tropical lake, Limnol. Oceanogr., 60, 553-572, 2015. 